\title{
Electronic structure and atomic structure peculiarities of isomorphic modified zine diphosphates
}

\author{
S.S.Smolyak, V.L.Karbivskyy, V.H.Kasiyanenko \\ G.V.Kurdumov Institute for Metal Physics, National Academy of Sciences \\ of Ukraine, 36 Acad. Vernadsky Blvd., 03680 Kyiv-142, Ukraine
}

Received October, 5, 2013

\begin{abstract}
Effects of partial substitution of $\mathrm{Zn}$ by $\mathrm{Mn}$ on the electronic and atomic structure of diphosphates $\mathrm{Zn}_{2-x} \mathrm{Mn}_{x} \mathrm{P}_{2} \mathrm{O}_{7} \cdot 5 \mathrm{H}_{2} \mathrm{O}(x=0.0,0.7)$ have been studied out by X-ray photoelectron spectroscopy, IR spectroscopy, NMR and thermogravimetric analysis. Analysis of the infrared absorption spectra was carried out for functional groups of $\mathrm{Zn}_{2} \mathrm{P}_{2} \mathrm{O}_{7} \cdot 5 \mathrm{H}_{2} \mathrm{O}$ and $\mathrm{Zn}_{1.3} \mathrm{Mn}_{0.7} \mathrm{P}_{2} \mathrm{O}_{7} \cdot 5 \mathrm{H}_{2} \mathrm{O}$ compounds. Through correlation between the symmetric and asymmetric stretching vibrations of $\mathrm{P}-\mathrm{O}-\mathrm{P}$ bridge and $\mathrm{P}-\mathrm{O}-\mathrm{P}$ angle an increase of $\mathrm{P}-\mathrm{O}-\mathrm{P}$ bridge angle was established for $\mathrm{Zn}_{1.3} \mathrm{Mn}_{0.7} \mathrm{P}_{2} \mathrm{O}_{7} .5 \mathrm{H}_{2} \mathrm{O}$. Substitution of zinc by manganese has little impact on the overall balance of chemical bond in the compound, which is manifested in minor changes of the core electrons binding energies.
\end{abstract}

\footnotetext{
Методами рентгеновской фотоэлектронной спектроскопии, ИК и ЯМР спектроскопии и термогравиметрического анализа исследовано влияние частичного замещения цинка марганцем на электронное строение и структурные параметры дифосфатов $\mathrm{Zn}_{2-}$ ${ }_{x} \mathrm{Mn}_{x} \mathrm{P}_{2} \mathrm{O}_{7} \cdot 5 \mathrm{H}_{2} \mathrm{O}(x=0.0,0.7)$. Проведен анализ ИК-полос поглощения, характеризующих колебания функциональных групп соединений $\mathrm{Zn}_{2} \mathrm{P}_{2} \mathrm{O}_{7} \cdot 5 \mathrm{H}_{2} \mathrm{O}$ и $\mathrm{Zn}_{1.3} \mathrm{Mn}_{0.7} \mathrm{P}_{2} \mathrm{O}_{7} \cdot 5 \mathrm{H}_{2} \mathrm{O}$. Исходя из корреляций симметричных и асимметричных валентных колебаний мостиковой связи P-O-P, установлено увеличение угла P-O-P в соединении $\mathrm{Zn}_{1.3} \mathrm{Mn}_{0.7} \mathrm{P}_{2} \mathrm{O}_{7} \cdot 5 \mathrm{H}_{2} \mathrm{O}$. Замещение цинка марганцем мало нарушает общий баланс химической связи в соединении, проявляющейся в незначительных изменениях энергий связи остовных уровней компонент.
}

Електронна будова і структурні особливості атомів ізоморфномодифікованого дифосфату цинку. С.С.Смоляк, В.Л.Карбівський, В.Х.Касіяненко.

За допомогою рентгенівської фотоелектронної спектроскопії, ІЧ і ЯМР спіктроскопії та термогравіметричного аналізу вивчено вплив ізоморфного заміщення цинку марганцем на електронну будову та структурні параметри дифосфатів $\mathrm{Zn}_{2-x} \mathrm{Mn}_{x} \mathrm{P}_{2} \mathrm{O}_{7} \cdot 5 \mathrm{H}_{2} \mathrm{O}(x=$ $0.0,0.7)$. Проведено аналіз ІЧ-смуг поглинання, що характеризують коливання функціональних груп сполук $\mathrm{Zn}_{2} \mathrm{P}_{2} \mathrm{O}_{7} \cdot 5 \mathrm{H}_{2} \mathrm{O}$ і $\mathrm{Zn}_{1.3} \mathrm{Mn}_{0.7} \mathrm{P}_{2} \mathrm{O}_{7} \cdot 5 \mathrm{H}_{2} \mathrm{O}$. Виходячи 3 кореляцій симетричних і асиметричних валентних коливань місткового зв'язку Р-O-P, встановлено збільшення кута $\mathrm{P}-\mathrm{O}-\mathrm{P}$ у сполуці $\mathrm{Zn}_{1.3} \mathrm{Mn}_{0.7} \mathrm{P}_{2} \mathrm{O}_{7} \cdot 5 \mathrm{H}_{2} \mathrm{O}$. Заміщення цинку марганцем мало порушує загальний баланс хімічного зв'язку у сполуці, що виявляється в незначних змінах енергій зв'язку остовних рівнів компонент.

\section{Introduction}

Currently, there is a growing interest in development of the new inorganic materials for practical applications. A wide range of industrial applications have phosphate materials, for example, diphosphates of lithium and polyvalent metals recently started to be used as electrode materials in autono- 
mous power sources [1-4]. No less interesting and promising for usage as electrode materials are diphosphates containing lithium and polyvalent metals in the lower oxidation states. For example $\mathrm{LiM}_{\mathrm{III}} \mathrm{P}_{2} \mathrm{O}_{7}$ or $\mathrm{Li}_{3} \mathrm{M}_{\mathrm{III} 2}\left(\mathrm{PO}_{4}\right)_{3}\left(\mathrm{M}_{\mathrm{III}}-\mathrm{Fe}, \mathrm{V}, \mathrm{Ti}, \mathrm{Mo}\right)$ [5].

Earlier it was studied the structural features of $\mathrm{Mn}_{2-x} \mathrm{Co}_{x} \mathrm{P}_{2} \mathrm{O}_{7} \cdot 5 \mathrm{H}_{2} \mathrm{O}$, which are promising materials for their use as pigments, catalysts and environmentally friendly corrosion inhibitors [6, 7]. Electronic structure of these compounds was investigated in [8]. Their electronic structure peculiarities were studied by us in [8]. The structural characteristics and thermal properties of diphosphates $\mathrm{Zn}_{2} \mathrm{P}_{2} \mathrm{O}_{7} \cdot 5 \mathrm{H}_{2} \mathrm{O}$ were reported in [9, 10]. The results of spectralluminescent and vibrational properties are presented in [11]. However, information about the electronic structure of $\mathrm{Zn}_{2} \mathrm{P}_{2} \mathrm{O}_{7} \cdot 5 \mathrm{H}_{2} \mathrm{O}$ is absent for now.

In this context, the aim of this work is to study the electronic structure features and structural characteristics of diphosphates $\mathrm{Zn}_{2} \mathrm{P}_{2} \mathrm{O}_{7} \cdot 5 \mathrm{H}_{2} \mathrm{O}$ and $\mathrm{Zn}_{1.3} \mathrm{Mn}_{0.7} \mathrm{P}_{2} \mathrm{O}_{7} \cdot 5 \mathrm{H}_{2} \mathrm{O}$.

\section{Experimental}

In the current work methods of X-ray photoelectron spectroscopy (XPS), infrared spectroscopy (IR), nuclear magnetic resonance spectroscopy (NMR) and thermogravimetry were used.

$\mathrm{X}$-ray photoelectron spectra of the samples - $\mathrm{Zn}_{1.3} \mathrm{Mn}_{0.7} \mathrm{P}_{2} \mathrm{O}_{7} \cdot 5 \mathrm{H}_{2} \mathrm{O}$ and $\mathrm{Zn}_{2} \mathrm{P}_{2} \mathrm{O}_{7} \cdot 5 \mathrm{H}_{2} \mathrm{O}$ were obtained by a photoelectron spectrometer of "JEOL" company - "JSPM-4610" with using of non-monochromatic $\mathrm{Mg} \mathrm{K}$ (1253.6 eV) X-ray source. Calibration of X-ray photoelectron spectra was carried out using the binding energy of gold Au $4 f$ lines, thus providing to obtain a sufficiently high determination accuracy of the electron binding energies for the samples elements. During the experiment, pressure in an analytical chamber was $10^{-7} \mathrm{~Pa}$, the accuracy of the binding energy determination was $0.1 \mathrm{eV}$. The samples were prepared as disperse powder deposited on the aluminium substrate.

NMR spectra were recorded on a "Bruker" Avance 400 spectrometer at the room temperature.

To obtain IR spectra, the samples were shaped as tablets. The transmission spectra were recorded in absorption band of $\mathrm{P}_{2} \mathrm{O}_{7}$ anion from $1300 \mathrm{~cm}^{-1}$ to $400 \mathrm{~cm}^{-1}$ using dual-beam spectrophotometer "Specord M80" (recording range 4000-250 $\mathrm{cm}^{-1}$ ).

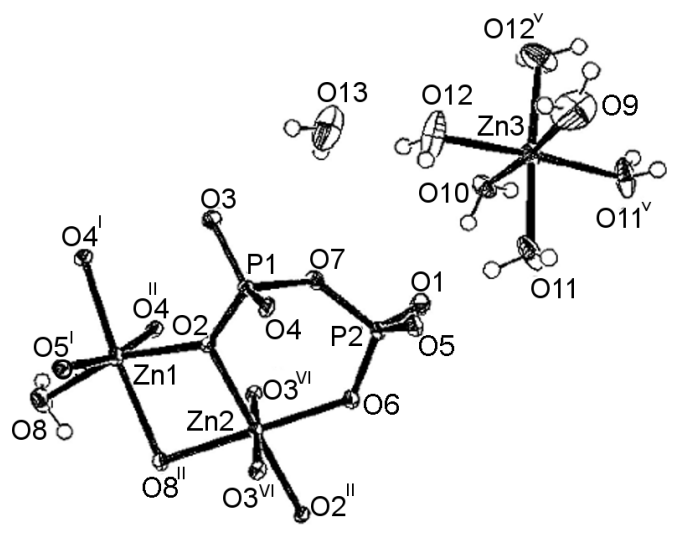

Fig. 1. Structure of $\mathrm{Zn}_{4}\left(\mathrm{P}_{2} \mathrm{O}_{7}\right)_{2} \cdot 10 \mathrm{H}_{2} \mathrm{O}$ [9].

Thermograms were recorded by Q-1500D derivatograph of MOM company. The samples with mass $\sim 40-50 \mathrm{mg}$ were studied in thermogravimetric platinum crucibles at temperature ranging from the room temperature up to $1000^{\circ} \mathrm{C}$ at a heating rate of $5^{\circ} \mathrm{C} / \mathrm{min}$, in air (limited area), at the free convection exchange.

\section{Results and discussion}

It is known [9] that $\mathrm{Zn}_{2} \mathrm{P}_{2} \mathrm{O}_{7} \cdot 5 \mathrm{H}_{2} \mathrm{O}$ crystallizes in orthorhombic symmetry with the space group $P_{n m a}\left(D_{2 h}{ }^{16}\right)$. In structure of $\mathrm{Zn}_{2} \mathrm{P}_{2} \mathrm{O}_{7} \cdot 5 \mathrm{H}_{2} \mathrm{O}$ there are present two crystallographically nonequivalent atoms of phosphorus forming groups $\mathrm{P}_{2} \mathrm{O}_{7}$, and three nonequivalent atoms of the metal. $\mathrm{Zn}_{2} \mathrm{P}_{2} \mathrm{O}_{7} \cdot 5 \mathrm{H}_{2} \mathrm{O}$ consists of packed layers of $\mathrm{ZnO}_{6}$ octahedra, connected by double tetrahedral $\mathrm{P}_{2} \mathrm{O}_{7}$-groups - $\left[\mathrm{Zn}_{3} \mathrm{O}_{2}\left(\mathrm{H}_{2} \mathrm{P}_{2} \mathrm{O}_{7}\right)_{2} \cdot 2 \mathrm{H}_{2} \mathrm{O}\right]$ and layers of [ $\left.\mathrm{Zn}(3)\left(\mathrm{H}_{2} \mathrm{O}\right)_{6}\right]$ groups (Fig. 1). $\mathrm{P}_{2} \mathrm{O}_{7}^{4-}$ anions have nonlinear configuration with $\mathrm{P}-\mathrm{O}-\mathrm{P}$ bridging angle equal to $126.5^{\circ}[6,9]$.

To assess the changes in the atomic structure of diphosphates $\mathrm{Zn}_{2-x} \mathrm{Mn}_{x} \mathrm{P}_{2} \mathrm{O}_{7} \cdot 5 \mathrm{H}_{2} \mathrm{O}$ $(x=0.0,0.7)$ infrared spectra were obtained (Fig. 2). IR spectra consist of different bands corresponding to the vibrations of water molecules, $\mathrm{PO}_{3}$ groups and $\mathrm{P}-\mathrm{O}-\mathrm{P}$ bridge. The assignment of frequencies for the both samples is given in Table 1. Position of the bands is consistent with the previous results [9], however, the number of observed vibrational modes does not correspond to the quantity provided by the compound symmetry. Apparently, this is due to the overlap of some bands or due to insufficient intensity of the individual modes [9]. Less number of the vibrational modes was also observed for $\alpha-\mathrm{Zn}_{2} \mathrm{P}_{2} \mathrm{O}_{7}, \alpha-, \beta-\mathrm{Mg}_{2} \mathrm{P}_{2} \mathrm{O}_{7}$ and 
Table 1. Vibrational band assignments for $\mathrm{Zn}_{2-x} \mathrm{Mn}_{x} \mathrm{P}_{2} \mathrm{O}_{7} \cdot 5 \mathrm{H}_{2} \mathrm{O}\left(\mathrm{cm}^{-1}\right)$

\begin{tabular}{|c|c|c||}
\hline \multicolumn{2}{|c|}{$\begin{array}{c}\text { Position of vibrational bands } \\
\text { for } \mathrm{Zn}_{2-x} \mathrm{Mn}_{x} \mathrm{P}_{2} \mathrm{O}_{7} \cdot 5 \mathrm{H}_{2} \mathrm{O}\left(\mathrm{cm}^{-1}\right)\end{array}$} & \multirow{2}{*}{ Assignment } \\
\cline { 1 - 2 }$x=0.0$ & $x=0.7$ & \\
\cline { 1 - 2 } 3712 & 3712 & $v^{2} \mathrm{H}_{2} \mathrm{O}$ \\
1648 & 1648 & $\mathrm{SH}_{2} \mathrm{O}$ \\
1144 & 1144 & $v_{s} \mathrm{PO}_{3}$ \\
1088 & 1080 & + \\
& 1040 & $v_{a s} \mathrm{PO}_{3}$ \\
912 & 912 & $v_{a s} \mathrm{POP}$ \\
744 & 736 & $v_{s} \mathrm{POP}$ \\
672 & & $\rho_{2} \mathrm{O}$ \\
560 & 552 & $\delta_{a s} \mathrm{PO}_{3}$ \\
488 & 480 & \\
\hline
\end{tabular}

$\mathrm{Ca}_{2} \mathrm{P}_{2} \mathrm{O}_{7}$, as expected according to the group of symmetry [9].

For the sample $\mathrm{Zn}_{2} \mathrm{P}_{2} \mathrm{O}_{7} \cdot 5 \mathrm{H}_{2} \mathrm{O}$ there are two modes $-1144 \mathrm{~cm}^{-1}$ and $1080 \mathrm{~cm}^{-1}$ in the area of symmetric and asymmetric stretching vibrations of $\mathrm{PO}_{3}$-groups. For the sample of diphosphate $\mathrm{Zn}_{2-x} \mathrm{Mn}_{x} \mathrm{P}_{2} \mathrm{O}_{7} \cdot 5 \mathrm{H}_{2} \mathrm{O}$ where $x=0.7$, the number of vibrational modes increases to three $-1144 \mathrm{~cm}^{-1}$, $1080 \mathrm{~cm}^{-1}$ and $1040 \mathrm{~cm}^{-1}$ (Fig. 2, Table 1).

Two absorption bands $-766 \mathrm{~cm}^{-1}\left(v_{s}\right)$ and $929 \mathrm{~cm}^{-1}\left(v_{a s}\right)$ correspond to the stretching vibrations of $\mathrm{P}-\mathrm{O}-\mathrm{P}$ bridge. The presence of these two modes in the spectrum indicates that the angle POP $<180^{\circ}$ and that the symmetry of $\mathrm{P}_{2} \mathrm{O}_{7}$-group cannot be higher than $C_{2 v}$, because only one mode vas can be observed for centrosymmetric (angle $\mathrm{POP}=180^{\circ}$ ) configuration (symmetry group $D_{3 d}$ ).

In the frequency range of $2500 \mathrm{~cm}^{-1}$ $3700 \mathrm{~cm}^{-1}$ there are observed the broad overlapping absorption bands corresponding to stretching vibrations of water molecules $v \mathrm{H}_{2} \mathrm{O}$, that can be explained by formation of various hydrogen bonds. This assumption is confirmed by the authors of $[6,9]$ for the analogous compounds. Deformation modes

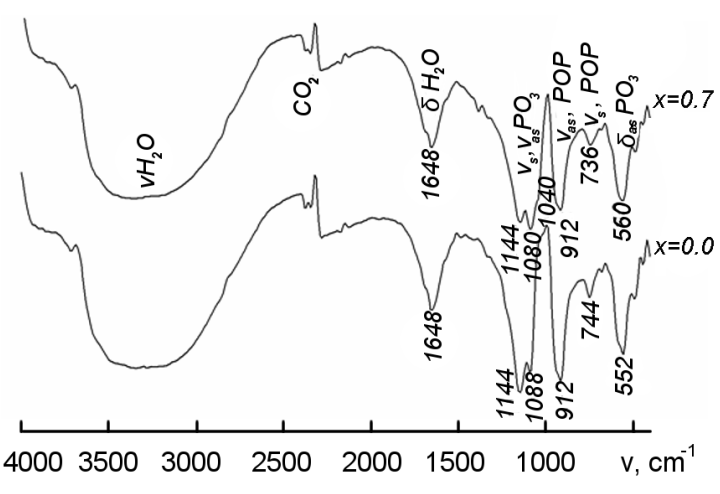

Fig. 2. IR absorption spectra of diphosphates $\mathrm{Zn}_{2-x} \mathrm{Mn}_{x} \mathrm{P}_{2} \mathrm{O}_{7} \cdot 5 \mathrm{H}_{2} \mathrm{O}$, where $x=0.0,0.7$.

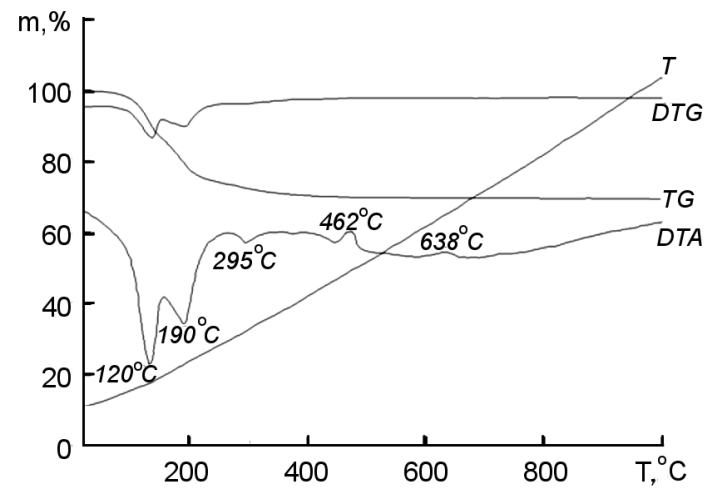

Fig. 3. DTA, TG and DTG curves of $\mathrm{Zn}_{2} \mathrm{P}_{2} \mathrm{O}_{7} \cdot 5 \mathrm{H}_{2} \mathrm{O}$.

of water molecules for the both samples are observed in the area of $1648 \mathrm{~cm}^{-1}$.

Position of observed vibrational modes $v_{s}$ and $v_{a s}$ can be used for the experimental determination of the POP angle in these compounds. To estimate the magnitude of the POP angle we used the relationship between the angle and the magnitude of splitting of $\mathrm{P}_{2} \mathrm{O}_{7}$-group vibrations proposed by Lazarev: $\quad \Delta=\left[v_{a s}-v_{s} \mathrm{POP}\right] /\left[v_{a s}+v_{s} \mathrm{POP}\right]$ [12]. Experimentally obtained dependence of this quantity $\Delta$ against the POP angle of $\mathrm{P}_{2} \mathrm{O}_{7}$-group is given in [13]. The values of POP angle for studied compounds obtained on the basis of these data are shown in Table 2 .

Table 2. Values of $100 \cdot \Delta$ and POP angle for the samples of $\mathrm{Zn}_{2-x} \mathrm{Mn}_{x} \mathrm{P}_{2} \mathrm{O}_{7} \cdot 5 \mathrm{H}_{2} \mathrm{O}(x=0.0,0.7)$

\begin{tabular}{|c|c|c|c|c||}
\hline & $\begin{array}{c}v_{a s} \mathrm{POP}, \\
\left(\mathrm{IR}, \mathrm{cm}^{-1}\right)\end{array}$ & $\begin{array}{c}v_{s} \mathrm{POP}, \\
\left(\mathrm{IR}, \mathrm{cm}^{-1}\right)\end{array}$ & $100 \cdot \Delta$ & $\begin{array}{c}\text { Angle POP, deg., } \\
\text { according to [13] }\end{array}$ \\
\hline $\mathrm{Zn}_{2} \mathrm{P}_{2} \mathrm{O}_{7} \cdot 5 \mathrm{H}_{2} \mathrm{O}$ & 912 & 744 & 10.14 & 125 \\
$\mathrm{Zn}_{1.3} \mathrm{Mn}_{0.7} \mathrm{P}_{2} \mathrm{O}_{7} \cdot 5 \mathrm{H}_{2} \mathrm{O}$ & 912 & 736 & 10.68 & 127 \\
\hline
\end{tabular}


Parameter $100 \cdot \Delta$ for $\mathrm{Zn}_{2} \mathrm{P}_{2} \mathrm{O}_{7} \cdot 5 \mathrm{H}_{2} \mathrm{O}$ is 10.14 that corresponds to angle of $125^{\circ}$, and practically coincides with the value obtained in [9], where the angle was determined as $126.5^{\circ}$. For compound $\mathrm{Zn}_{1.3} \mathrm{Mn}_{0.7} \mathrm{P}_{2} \mathrm{O}_{7} \cdot 5 \mathrm{H}_{2} \mathrm{O}$ the parameter $100 \cdot \Delta$ is 10.68, that corresponds to the angle POP equal to $127^{\circ}$.

The nature of thermal processes in the temperature range from $\approx 20^{\circ} \mathrm{C}$ to $1000^{\circ} \mathrm{C}$ for diphosphates $\mathrm{Zn}_{2-x} \mathrm{Mn}_{x} \mathrm{P}_{2} \mathrm{O}_{7} \cdot 5 \mathrm{H}_{2} \mathrm{O} \quad(x=$ $0.0,0.7)$ can be seen from the curves of DTA, TG and DTG (Fig. 3, Fig 4).

Thus on the DTA curve for $\mathrm{Zn}_{2} \mathrm{P}_{2} \mathrm{O}_{7} \cdot 5 \mathrm{H}_{2} \mathrm{O}$ (Fig. 3, Table 3) there are two deep minima at $120^{\circ} \mathrm{C}$ and $190^{\circ} \mathrm{C}$ and weak minimum at $295^{\circ} \mathrm{C}$ corresponding to endoeffects. These effects are caused by the mass loss - removal of water molecules at different stages. The DTG curve indicates that the processes of mass loss proceed in three stages. Exoeffects at $462^{\circ} \mathrm{C}$ and $638^{\circ} \mathrm{C}$ are not accompanied by loss of mass and probably is due to crystallization of intermediary products. This is consistent with the results obtained in [9] for compound $\mathrm{Zn}_{2} \mathrm{P}_{2} \mathrm{O}_{7} \cdot 5 \mathrm{H}_{2} \mathrm{O}$, where at $295^{\circ} \mathrm{C}$ the amorphous $\mathrm{Zn}_{2} \mathrm{P}_{2} \mathrm{O}_{7}$ was observed, at $481^{\circ} \mathrm{C}$ the crystallization of $\gamma-\mathrm{Zn}_{2} \mathrm{P}_{2} \mathrm{O}_{7}$ took place and at $750^{\circ} \mathrm{C}$ the transformation of the $\gamma$-phase in $\beta-\mathrm{Zn}_{2} \mathrm{P}_{2} \mathrm{O}_{7}$ occurred. The transition between the $\gamma-Z n_{2} P_{2} O_{7}$ and $\beta-Z n_{2} P_{2} O_{7}$ is irreversible, but cooling of $\beta-\mathrm{Zn}_{2} \mathrm{P}_{2} \mathrm{O}_{7}$ to the room temperature leads to formation of $\alpha-\mathrm{Zn}_{2} \mathrm{P}_{2} \mathrm{O}_{7}$ [9].

Presence in the sample of $\mathrm{Zn}_{2-x} \mathrm{Mn}_{x} \mathrm{P}_{2} \mathrm{O}_{7} \cdot 5 \mathrm{H}_{2} \mathrm{O}$ two types of cations

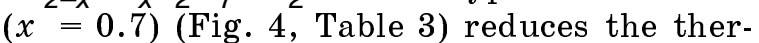
mal stability - the weaker bonds of water molecules broken at $82.5^{\circ} \mathrm{C}$ (see the curve DTG). This is evidenced by the endotherm

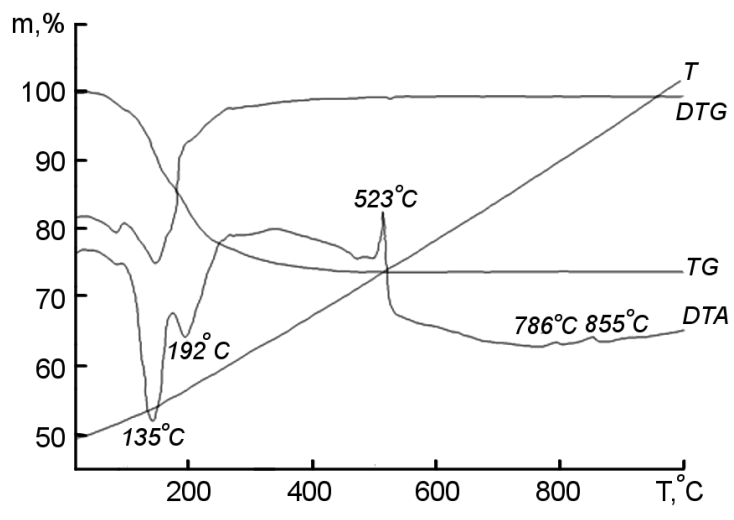

Fig. 4. DTA, TG and DTG curves of $\mathrm{Zn}_{2-x} \mathrm{Mn}_{x} \mathrm{P}_{2} \mathrm{O}_{7} \cdot 5 \mathrm{H}_{2} \mathrm{O}, x=0.7$.

effect on the DTA curve at this temperature. The deep endoeffect with a minimum at $135^{\circ} \mathrm{C}$ is accompanied by a significant loss of mass and the highest rate of the mass loss. The less intensive endoeffect at $192^{\circ} \mathrm{C}$ is characterized by the minor loss of mass. There is also a low-intensity endoeffect at $270^{\circ} \mathrm{C}$. The DTG curve confirms the jagged mass loss model. Unlike $\mathrm{Zn}_{2} \mathrm{P}_{2} \mathrm{O}_{7} \cdot 5 \mathrm{H}_{2} \mathrm{O}$, for compound $\mathrm{Zn}_{1.3} \mathrm{Mn}_{0.7} \mathrm{P}_{2} \mathrm{O}_{7} \cdot 5 \mathrm{H}_{2} \mathrm{O}$ three exoeffects at temperatures $523^{\circ} \mathrm{C}, 786^{\circ} \mathrm{C}$ and $855^{\circ} \mathrm{C}$ are observed, which are associated with transformations of the heated material without the loss of mass.

Infrared spectroscopy is very informative method for studying the heating products, because of removal of functional groups during the heating of the substance reduces or totally eliminates the intensity of the corresponding absorption band. Heating of the test compounds (up to $1000^{\circ} \mathrm{C}$ ) leads to a loss of water molecules. (?) - IR spectra of the samples have no vibrational modes corresponding to the water molecules (this area is not presented here). IR spectra of the heating products of the studied com-

Table 3. Peak positions of the thermal effects $\left({ }^{\circ} \mathrm{C}\right)$ for $\mathrm{Zn}_{2-x} \mathrm{Mn}_{x} \mathrm{P}_{2} \mathrm{O}_{7} \cdot 5 \mathrm{H}_{2} \mathrm{O}$

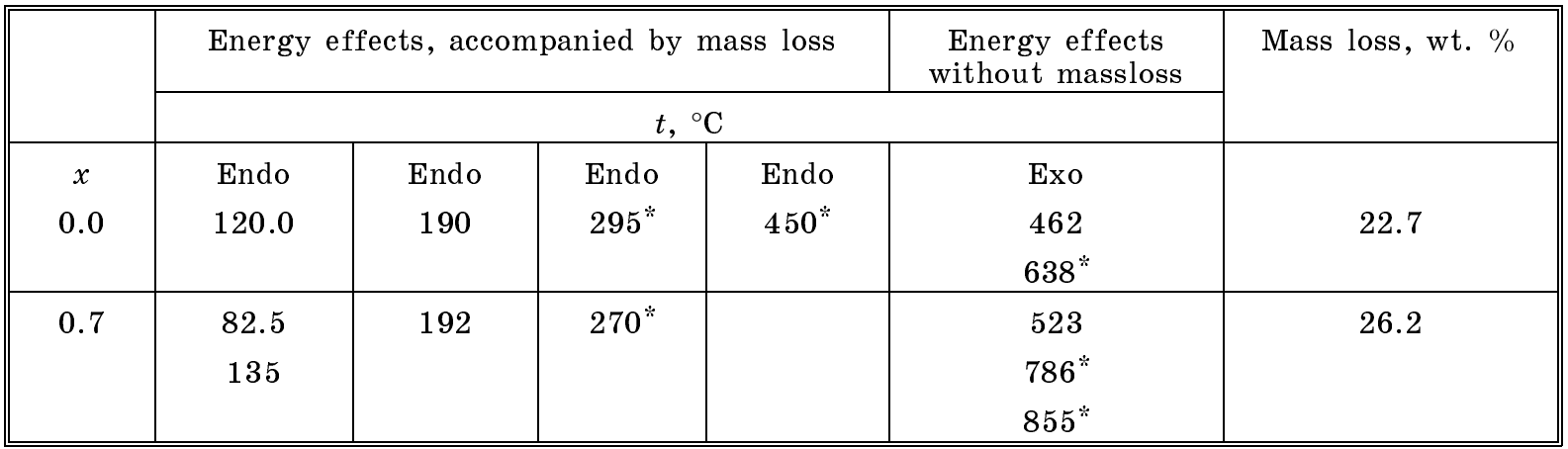

Note: * - weak intensity. 


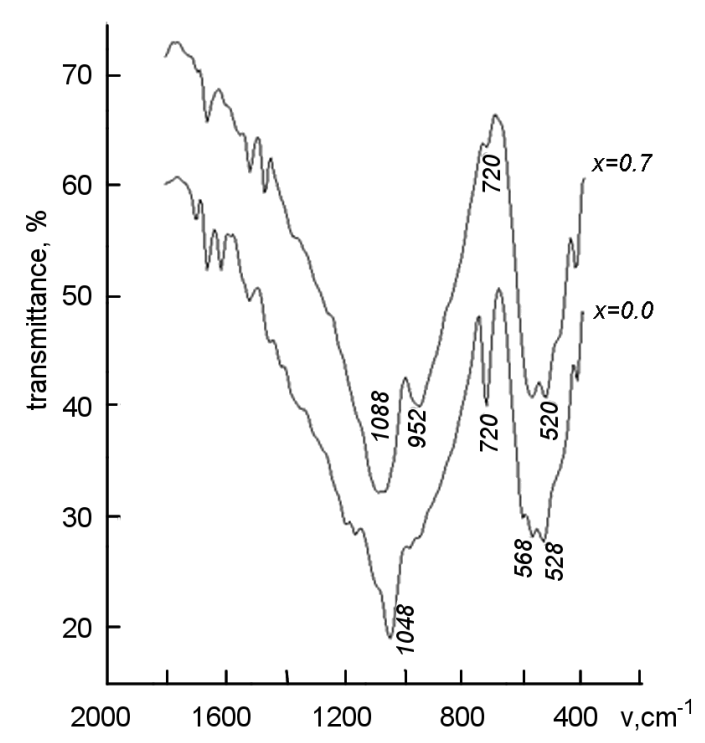

Fig. 5. IR absorption spectra of diphosphates $\mathrm{Zn}_{2-x} \mathrm{Mn}_{x} \mathrm{P}_{2} \mathrm{O}_{7} \cdot 5 \mathrm{H}_{2} \mathrm{O}(x=0.0,0.7)$, heated up to $1000^{\circ} \mathrm{C}$.

pounds (see Fig. 5) have vibration modes corresponding to $v_{s}$ POP, that indicates the curved shape of the POP bridge. Shift of the vibrational modes $v_{s} \mathrm{POP}$ after heating is observed for the both samples to the lower frequencies on $16 \mathrm{~cm}^{-1}$ and $24 \mathrm{~cm}^{-1}$ with respect to the samples in the initial state. A significant shift towards the higher frequencies is observed for $v_{a s}$ POP mode. According to [12], decrease of $v_{s}$ POP frequency and increase of $v_{a s}$ POP frequency indicates the increase of POP angle. Spectroscopic evaluation of the angle for the heating products of these compounds shows that in the case of $\mathrm{Zn}_{2} \mathrm{P}_{2} \mathrm{O}_{7} \cdot 5 \mathrm{H}_{2} \mathrm{O}$ the final product has POP angle equal to $\sim 140^{\circ}$. It is assumed that the heating of this compound led to the formation of $\alpha-\mathrm{Zn}_{2} \mathrm{P}_{2} \mathrm{O}_{7}$ phase, because it is known from [9] that heating of $\mathrm{Zn}_{2} \mathrm{P}_{2} \mathrm{O}_{7} \cdot 5 \mathrm{H}_{2} \mathrm{O}$ results in formation of $\alpha-\mathrm{Zn}_{2} \mathrm{P}_{2} \mathrm{O}_{7}$ with POP angle equal to $139^{\circ}$. IR spectrum of the heating product of $\mathrm{Zn}_{2-x} \mathrm{Mn}_{x} \mathrm{P}_{2} \mathrm{O}_{7} \cdot 5 \mathrm{H}_{2} \mathrm{O}, \quad x=0.7$ is more blurred, $v_{s}$ POP mode has low-intensity and POP angle is about $148^{\circ}$.

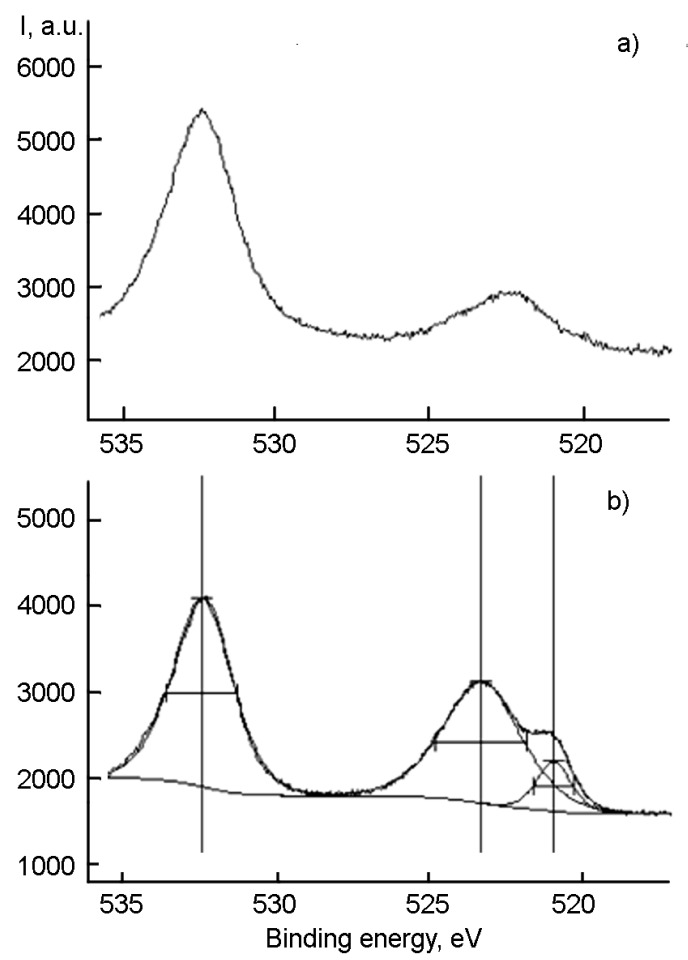

Fig. 6. $\mathrm{O} 1 \mathrm{~s}$ XPS spectra for $\mathrm{Zn}_{2} \mathrm{P}_{2} \mathrm{O}_{7} \cdot 5 \mathrm{H}_{2} \mathrm{O}$ (a) and $\mathrm{Zn}_{1.3} \mathrm{Mn}_{0.7} \mathrm{P}_{2} \mathrm{O}_{7} \cdot 5 \mathrm{H}_{2} \mathrm{O}$ (b).

From comparison of the thermal effects temperatures for $\mathrm{Zn}_{2-x} \mathrm{Mn}_{x} \mathrm{P}_{2} \mathrm{O}_{7} \cdot 5 \mathrm{H}_{2} \mathrm{O}, x=0.0$, 0.7 it is seen that the sample with the value of $x=0.0$ is more resistant to the thermal stresses.

Electronic structure of the investigated compounds was studied by X-ray photoelectron spectroscopy. Fig. 6 shows the XPS spectra of $1 \mathrm{~s}$ states of oxygen, which are characterized by approximately the same parameters. One can see that their energy position, width and asymmetry parameter are almost matching. As can be seen from Table 4, the partial substitution of zinc by manganese is accompanied by some increase in the energy of $2 p$ core electrons of zinc by $0.2 \mathrm{eV}$. Such small changes in the positions of the core electrons spectra indicate the spatial redistribution of the electron density while maintaining the overall energy balance of the chemical bond.

Participation in the bond of $3 d$-orbitals of manganese results in significant broaden-

Table 4. Binding energy (eV) of the core levels of atoms for the studied compounds

\begin{tabular}{|c|c|c|c|c|c||}
\hline & $\mathrm{O} 1 s$ & $\mathrm{Zn} 2 p_{3 / 2}$ & $\mathrm{Zn} 2 p_{1 / 2}$ & $\mathrm{Mn} 2 p_{3 / 2}$ & $\mathrm{Mn} 2 p_{1 / 2}$ \\
\hline $\mathrm{Zn}_{2} \mathrm{P}_{2} \mathrm{O}_{7} \cdot 5 \mathrm{H}_{2} \mathrm{O}$ & 532.5 & 1023.4 & 1046.5 & - & - \\
$\mathrm{Zn}_{1.3} \mathrm{Mn}_{0.7} \mathrm{P}_{2} \mathrm{O}_{7} \cdot 5 \mathrm{H}_{2} \mathrm{O}$ & 532.5 & 1023.5 & 1046.7 & 642.8 & 654.5 \\
\hline
\end{tabular}




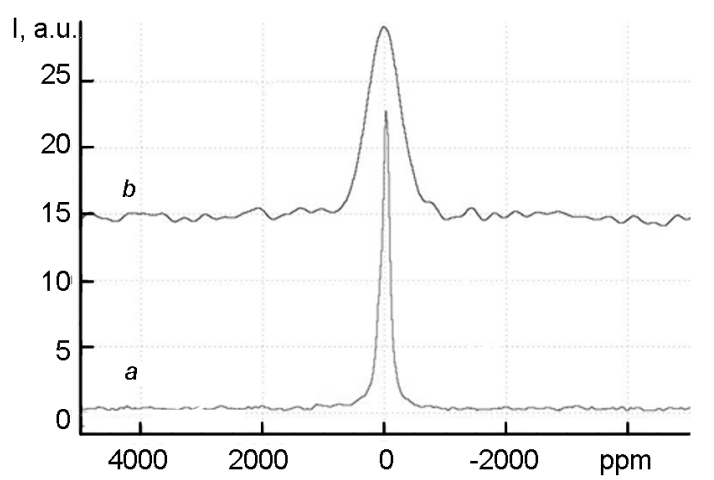

Fig. 7. ${ }^{31} \mathrm{P}$ NMR spectra of compounds: a) $\mathrm{Zn}_{2} \mathrm{P}_{2} \mathrm{O}_{7} \cdot 5 \mathrm{H}_{2} \mathrm{O} ;$ b) $-\mathrm{Zn}_{1.3} \mathrm{Mn}_{0.7} \mathrm{P}_{2} \mathrm{O}_{7} \cdot 5 \mathrm{H}_{2} \mathrm{O}$.

ing of the nuclear magnetic resonance spectra obtained on the nuclei of phosphorus ${ }^{31} \mathrm{P}$ (Fig. 7). This broadening is caused by the presence of magnetic moment on manganese atoms due to the existence of its unpaired electrons on $3 d$-orbitals, that leads to the broadening of ${ }^{31} \mathrm{P}$ NMR line.

\section{Conclusions}

For zinc diphosphate the value of $\mathrm{P}-\mathrm{O}-\mathrm{P}$ bridge angle was determined, which is equal to $125^{\circ}$. Isomorphic substitution of zinc by manganese $-\mathrm{Zn}_{1.3} \mathrm{Mn}_{0.7} \mathrm{P}_{2} \mathrm{O}_{7} \cdot 5 \mathrm{H}_{2} \mathrm{O}$ leads to a slight increase in the $\mathrm{P}-\mathrm{O}-\mathrm{P}$ bond angle, which amount to $127^{\circ}$.

Annealing of the samples of $\mathrm{Zn}_{2} \mathrm{P}_{2} \mathrm{O}_{7} \cdot 5 \mathrm{H}_{2} \mathrm{O}$ and isomorphically substituted $\mathrm{Zn}_{1.3} \mathrm{Mn}_{0.7} \mathrm{P}_{2} \mathrm{O}_{7} \cdot 5 \mathrm{H}_{2} \mathrm{O}$ at $1000^{\circ} \mathrm{C}$ leads to the phase transformations and to significant increase in the angles of $\mathrm{P}-\mathrm{O}-\mathrm{P}$ bond, which are equal to $139^{\circ}$ and $148^{\circ}$, respectively.

Loss of structural water for $\mathrm{Zn}_{2} \mathrm{P}_{2} \mathrm{O}_{7} \cdot 5 \mathrm{H}_{2} \mathrm{O}$ compound take place at the higher temperatures, that indicates the presence of stronger hydrogen bonds and more stable structure of this compound. Doping of zinc diphosphate reduces the thermal stability of the compound. The weaker bonds of water molecules break even at $82.5^{\circ} \mathrm{C}$.

Isomorphic doping of zinc diphosphate by manganese has little impact on the overall balance of the chemical bond in the compound, which is manifested in minor changes of the core electrons binding energies.

\section{References}

1. T.Kanazawa, Inorganic Phosphate Materials, Tokio: Kodansha Ltd., (1989).

2. Z.Shi, Q.Wang, W.Ye et al., Micropor. and Mesopor. Mater., 88, 232 (2006).

3. I.V.Zatovsky, Dopovidi Nat.Akad.Nauk Ukrayiny, 11, 129 (2008).

4. A.Jouini, J.C.Gacon, M.Ferid et al., Opt. Mater., 24, 175 (2003).

5. G.-A.Nazri, G.Pistoia, Lithium Batteries. Science and Technology, Springer, Berlin (2004).

6. N.V.Tkachova, Thesis for the Degree of Candidate of Chemical Science, Kyiv (2009).

7. V.L.Karbivskyy, S.S.Smolyak, Yu.A.Zagorodniy et al., Nanosyst., Nanomater. Nanotechnol., 10, 123 (2012).

8. V.L.Karbivskyy, S.S.Smolyak, Yu.A.Zagorodniy et al., Functional Materials, 19, 459 (2012).

9. H.Assaaoudi, I.S.Butler, J.Kozinski et al., Journal of Chemical Crystallography, 35, 49 (2005).

10. M.Baril, H.Assaaoudi, J.A.Kozinski et al., Inorgan, Chim, Acta, 360, 3155 (2007).

11. G.I.Gaididei, O.V.Homenyuk, S.G.Nedel'ko, Fiz.Tverd. Tela, 47, 1486 (2005).

12. A.N.Lazarev, Vibrational Spectra and Structure of Silicates, Nauka, Leningrad (1968) [in Russian].

13. M.Harcharras, A.Ennaciri, A.Rulmont, B.Gilbert, Spectrochim. Acta, Part A, 53, 345 (1997). 